\title{
Letter to the Editor: Testosterone priming increased growth hormone peak levels in the stimulation test and suppressed gonadotropin secretion in three Japanese adolescent boys
}

\author{
Kentaro Sawano ${ }^{1}$ and Keisuke Nagasaki ${ }^{1}$ \\ ${ }^{I}$ Department of Pediatrics, Niigata University Medical and Dental Hospital, Niigata, Japan
}

Key words: priming, testosterone, GH deficiency (GHD)

Dear Editor,

We read with interest the article by Sato et al., entitled "Testosterone priming increased growth hormone peak levels in the stimulation test and suppressed gonadotropin secretion in three adolescent Japanese boys" in Clinical Pediatric Endocrinology (1). $\mathrm{GH}$ responsiveness to the GH stimulation test (GHST) is attenuated during the period just before puberty; however, testosterone priming may prevent unnecessary GH treatment (2). We reported two adolescent boys with suspected severe GH deficiency (GHD) in whom GH response normalized after testosterone priming.

Case 1: An 11-yr-old boy with reduced growth rate was diagnosed with severe GHD via GHST. A clonidine test and arginine test administered at another hospital revealed peak GH levels of 1.06 and $1.26 \mathrm{ng} /$ $\mathrm{mL}$, respectively. The patient's height was $144.5 \mathrm{~cm}$ $(-0.19 \mathrm{SD})$, and he weighed $83.5 \mathrm{~kg}$. His serum IGF I and testosterone levels were $156 \mathrm{ng} / \mathrm{mL}(-1.5 \mathrm{SD})$ and $0.14 \mathrm{ng} / \mathrm{mL}$, respectively. One week after testosterone priming with a $125 \mathrm{mg}$ intramuscular injection, his peak
GH levels, as measured by an insulin torelance test (ITT) and GH-releasing peptide-2 stimulation test, were 10.2 and $21.97 \mathrm{ng} / \mathrm{mL}$, respectively. Moreover, his annual growth rate increased by $9 \mathrm{~cm}$ without $\mathrm{GH}$ replacement therapy. Case 2: A 13-yr-old boy with short stature was diagnosed with severe GHD via GHST. A clonidine test and arginine test revealed peak $\mathrm{GH}$ levels of 0.93 and $0.64 \mathrm{ng} / \mathrm{mL}$, respectively. His height was $139.1 \mathrm{~cm}$ (-2.2 SD), and his weight was $41.5 \mathrm{~kg}$. His serum IGF I and testosterone levels were $113 \mathrm{ng} / \mathrm{mL}(-2.3 \mathrm{SD})$ and $0.15 \mathrm{ng} / \mathrm{mL}$, respectively. One week after testosterone priming, his peak GH levels, as measure by an ITT and arginine test, were 9.2 and $5.2 \mathrm{ng} / \mathrm{mL}$, respectively. He is undergoing follow-up without GH replacement therapy.

Results of our case studies show that testosterone priming improves $\mathrm{GH}$ responsiveness, even in cases of suspected severe GHD.

Conflicts of interests: The authors declare no conflicts of interest associated with this manuscript.

\section{References}

1. Sato T, Kusakawa M, Ichihashi Y, Ishii T, Hasegawa T. Testosterone priming increased growth hormone peak levels in the stimulation test and suppressed gonadotropin secretion in three Japanese adolescent boys. Clin Pediatr Endocrinol 2020;29: 119-21. [Medline] [CrossRef]

2. Grimberg A, DiVall SA, Polychronakos C, Allen DB, Cohen LE, Quintos JB, et al. Drug and Therapeutics Committee and Ethics Committee of the Pediatric Endocrine Society. Guidelines for growth hormone and insulin-like growth factor-I treatment in children and adolescents: growth hormone deficiency, idiopathic short stature, and primary insulin-like growth factor-I deficiency. Horm Res Paediatr 2016;86: 361-97. [Medline] [CrossRef]

Received: July 30, 2020 Accepted: August 3, 2020

Corresponding author: Keisuke Nagasaki, M.D., Ph.D., Department of Pediatrics, Niigata University Medical and Dental Hospital, 1-757 Asahimachi-Dori, Chuo-ku, Niigata City, Niigata 951-8510, Japan

E-mail: nagasaki@med.niigata-u.ac.jp 